\title{
Editorial
}

\section{The World Bank's New IT Strategy Adopted by Singapore}

The World Bank has released an ICT Sector Strategy paper that presents a roadmap that is designed around three directions. These are: Connect by expanding affordable access to voice, high-speed Internet, and information and media networks; Innovate by using ICT for innovation across the economy and promoting the growth of IT-based service industries; and Transform by supporting ICT applications to transform efficiency and accountability of services for increased development results. The rationale for the new strategy is based on a number of disruptive changes that have taken place in recent years, calling for a new approach by the World Bank Group relating to ICT.

This new initiative by World Bank underscores its commitment to "help client countries leapfrog development and become leaders in the digital future. By leveraging ICT infrastructure and innovation, countries can transform government and business services, increase productivity and competitiveness to achieve inclusive smart growth and improve the reach, efficien- cy and accountability of poverty reduction efforts. Although its client countries are developing economies, this new strategy can and should become a roadmap for the more advanced economies.

Singapore has already embraced the essential features of the World Bank's program. The government recently announced the Masterplan for Collaborative Government (eGov 2015). Its vision is to be a collaborative government that co-creates and connects with people. The plan will guide government agencies with in the implementation of new ICT programs in the next five years. It was developed with inputs from the people, private and public sectors, building on the success of previous e-Government plans. This issue of the Journal presents extensive details of Singapore's impressive initiatives.

Russell Pipe, Editor in Chief 